Bangladesh J. Sci. Ind. Res. 41(1-2), 63-66, 2006

\title{
Nutritional Value and Use of Shrimp Head Waste as Fish Meal
}

\author{
A. Nargis, K. N. Ahmed, G. M. Ahmed, M. A. Hossain and Munsur Rahman \\ BCSIR Laboratories, Rajshahi- 6206, Bangladesh
}

\begin{abstract}
The different parameters on physico-chemical characteristics especially the free fatty acid (FFA), peroxide values, iodine values, lipid class composition and major elements of shrimp head waste were studied. The oil was fractionated into mono, di and triglycerides by silicic acid column chromatography. The calcium ranged from $3.26 \mathrm{mg} / 100 \mathrm{gm}$ to $5.08 \mathrm{mg} / 100 \mathrm{gm}$, magnesium $4.79 \mathrm{mg} / 100 \mathrm{gm}$ to $7.02 \mathrm{mg} / 100 \mathrm{gm}$, sodium $51.09 \mathrm{mg} / 100 \mathrm{gm}$ to $73.05 \mathrm{mg} / 100 \mathrm{gm}$ and potassium $52.91 \mathrm{mg} / 100 \mathrm{gm}$ to $83.07 \mathrm{mg} / 100 \mathrm{gm}$ respectively. The percentage of crude protein is 49.47 .
\end{abstract}

\section{Introduction}

A huge quantity of shells of different kinds of shrimps and their wastes are carelessly dropped elsewhere from different Fish processing plants and Chinese restaurant especially in the Southern districts of Bangladesh. These wastes create heavy bad smell (odours) and pollute the environment to great extent. Continued production of the shrimps head waste without corresponding development of technology utilizing the wastes has resulted in waste collection, disposal and pollution problems. ${ }^{1}$ These unused shells of shrimps are sources of protein, fat and minerals and can offer a potential source for exploitation as fish feed.
A possibility is the use of shrimp head waste as meal which contains high levels of protein with excellent amino acid profile and it is comparable to that of fish meal. ${ }^{2}$ The purpose of this study is to determine the percentage of oil, crude protein, free fatty acid, iodine value, lipid composition and major elements viz. calcium, magnesium potassium and sodium etc.

\section{Materials and Methods}

Fresh shrimp waste (comprising mainly heads, shells) of Penaens monodon, Macrobrachium rosenbergii were collected from the Chinese Restaurants of Rajshahi. 
Immediately after collection, the samples were semi dried in an electric oven at $60^{\circ} \mathrm{C}$. Then these are blended in an electric blender. The oil of semi dried samples was extracted with n-Hexane in a Soxhlet Apparatus for 8 hours. n-Hexane as extracted solvent has been selected because this solvent has better effect over other polar solvents like alcohol, ketone, aldehyde, ester, etc. ${ }^{3}$ The analytical constants of oil were determined by the standard AOAC method. ${ }^{4}$ The crude oil was pooled and stored in a glass vials at $15^{\mathrm{O}} \mathrm{C}$ and lipid analysis was conducted after extraction as soon as possible.

Three major lipid classes of crude oil were separated by silicic acid (E. merck, Darmstadt, W. German, 70-230 mesh) column chromatography with elution rates of $0.5-1.0 \mathrm{mi} / \mathrm{min}$ with all solvent. ${ }^{5}$ The chloroform fraction contained neutral lipid, the acetone fractions contained glycolipids and FFA and methanol fraction contained phospholipids. Hanus method ${ }^{6}$ was applied to determine the iodine value of the oil. The weitht percentages of each lipid class was dependent on the total weight of lipid recovered with average $99.14 \%$ of the crude oil applied. Glycolipid were calculated by subtracting the weight of FFA as determined by AOAC method from the weight of acetone fraction. The mineral contents were determined by titrametrically and spectrophotometri-cally. The analysis of nitrogen was carried out by micro-kje1dhal method.

\section{Results and Discussion}

The results of the investigation in oil content of shrimp's shell are given in Table I. The percentage of oil is 2.5. Free fatty acid as

Table I. Physical and chemical characteristics of shrimp's shell oil

\begin{tabular}{c|l|c}
\hline SL. & Parameters & $\begin{array}{c}\% \\
\text { No. }\end{array}$ \\
\hline 1 & Oil & 2.5 \\
2 & Moisture & 78.25 \\
3 & Ash & 18.39 \\
4 & Melting point & $29-30^{\circ} \mathrm{C}$ \\
5 & Refraction index at $30^{\circ} \mathrm{C}$ & 1.231 \\
6 & Specific gravity at $30^{\mathrm{O}} \mathrm{C}$ & 0.903 \\
7 & Free fatty acid as oleic & 4.93 \\
8 & Saponification value & 192.09 \\
9 & Unsaponification & 1.57 \\
10 & Acid value & 9.81 \\
11 & Iodine value & 66.0 \\
12 & Peroxide value & 72.50 \\
13 & Crude protein & 49.47 \\
\hline
\end{tabular}

oleic is $4.93 \%$, iodine value is $66 \%$, peroxide value $72.50 \%$. It has crude protein of $49.47 \%$. The crude protein of $49.47 \%$ obtained showed that shrimp's head waste was rich in protein. Nwanna worked on fermented shrimp head silage replacement of fish meal by African Catfish Clarias gariepinus. ${ }^{7}$ She got the percentage of crude protein as $58.96 \%$ which is higher than our findings 
but may be compared favorably to he crude protein of $51.2 \%$ obtained from formic acid ensiled shrimp head silage meal. ${ }^{8}$ The discrepancy in the values is attributable to the effects of biological and chemical insolation. $^{9}$ The lipid composition and mineral content are presented in Tables II and III. The neutral lipid is $31.64 \%$, glycolipid $10.54 \%$ and phospolipid $59.96 \%$. Table III also show that it is a good source of calcium, magnesium, sodium and potassium.

Table II. Lipid composition of shrimp's shell oil

\begin{tabular}{c|c|c}
\hline Neutral lipid \% & Glycolipid\% & Phospolipid \% \\
\hline 31.64 & 10.54 & 56.96 \\
\hline
\end{tabular}

Table III. Mineral content of shrimp shell oil

\begin{tabular}{c|c|c}
\hline Mineral & Mean \pm SD $(\mathrm{mg} / 100 \mathrm{gm})$ & $\mathrm{Cv}$ \\
\hline $\mathrm{Ca}$ & $4.116 \pm 0.914$ & 0.557 \\
$\mathrm{Mg}$ & $5.967 \pm 1.12$ & 1.243 \\
$\mathrm{Na}$ & $64.15 \pm 11.555$ & 74.132 \\
$\mathrm{~K}$ & $59.99 \pm 15.089$ & 56.197 \\
\hline $\mathrm{N}=3$
\end{tabular}

The cv of calcium, magnesium, sodium and potassium are $0.5577,1.243,74.132$ and $50.197 \mathrm{mg} / 100 \mathrm{gm}$ respectively (Table III). Meyers and Hall et al. also described about the utilization of shrimp processing waster. Harnessing of these waster into fish feed production could serve as an excellent means of sanitizing the environment. ${ }^{10,11}$ Thus in conclusion, it may be stated that the shrimp waste (head and shell) may successfully be used to prepare highly proteinous supplementary feed for fish.

\section{References}

1. J. Raa and A. Gilberg. Fish Spoilage- A reviews. Critical Rev. Food Soc. Nutr. 6 (1982) 383-419.

2. H. A. Waldron and D. Stofen. Sub-clinical Lead Poisoning. Academic Press (1974) New York.

3. Official and Tentative Methods of the American Oil Chemists Society, Vol. I and II, 3rd Ed. (1980).

4. AOAC (Association of Official Analytical Chemists),. Official Methods of Analysis (15th ed.) AOAC inc. Artington, Virginia, USA, (1990) 1094.

5. G. Rouser, G. Kritchevsky and Yamamoto, Lipid Cromatography Analysis, Vol. 1, marinetti, G. V. Edition, Marcel Dekker, Inc., New York, (1967) 99-162.

6. Sr. R. J. Horn, S. Kottun and A. V. Graci. Jr. JAOCS 59 (1982) 674 A.

7. L. C. Nwanna, A. M. Balogun, Y. F. Ajenifuja and V. N. Enjiugha. Replacement of fish meal with chemically preserved shrimp head meal in the diets of African 
Catfish, Clarisa gariepinus. J. Food Agri. And Environ. 2 (2003) in press.

8. C. J. Fox, P. Blaw, J. H. Brown and I. Watson. The effects of various processing methods on the physical and biochemical properties of shrimp head meals and their utilization by Juvenile Penaeus monodon Fab. Aquaculture, 122 (1994) 209-226.

9. J. A. Robertson, G. W. Chapman, Jr. and R. L. Wilson. Jr. Lipid. 55 (1978) 266.
10. S. P. Meyers. Utilization of shrimp processing wastes. Infofish. Marketing Dig. 4/86 (1986) 18-19.

11. G. M. Hall and S. S. DeSilva. Shrimp waste ensilation. Infofish Int. 2/94 (1994) 27-30. 